\title{
FILOSOFI MENDIRIKAN KERAMAT MENURUT AGAMA HINDU KAHARINGAN
}

\author{
Oleh: Mariatie*
}

\begin{abstract}
Abstrak
Pengaruh agama dalam kehidupan berbudaya dan sebaliknya telah menciptakan suatu tradisi yang beraneka ragam. Dialektika hubungan agama dan tradisi terjadi dalam masyarakat yang digolongkan dalam golongan tradisional (Parlin, 2000). Hindu sebagai salah satu agama yang diakui keberadaannya di Indonesia dengan seperangkat nilainya telah mempengaruhi pola budaya dan tradisi pemeluknya. Sebagai contoh adalah Mendirikan Keramat yang mengandung nilai adat dan budaya ditinjau dari sarana dan prasarana upacara tersebut yang selalu diyakikni oleh masyarakat Hindu Kaharingan dan merupakan suatu tradisi leluhur secara turun temurun diperhatikan, dilestarikan sampai saat sekarang ini sehingga menjadi sebuah adat atau tradisi.

Permasalahan pokok, yakni:(1). Bagaimana filosofi Keramat bagi umat Hindu Kaharingan. (2). Apa fungsi Keramat bagi umat Hindu Kaharingan. (3). Bagaimana syarat dan proses mendirikan Keramat bagi umat Hindu Kaharingan.

Pembahasan sampai kesimpulan dalam penulisan ini, dapat dideskripsikan sebagai berikut: (1). Filosofi Keramat bagi umat Hindu Kaharingan dari dulu hingga sekarang masih di taati dan diyakini, hal itu mendapat pengakuan dari masyarakat secara turun temurun dan di dukung oleh kepercayaan agama Hindu Kaharingan terkait dengan kepercayaan yang gaib dan sakral. (2). Fungsi dan manfaat Keramat adalah berfungsi sebagai tempat pemujaan bagi umat Hindu Kaharingan untuk memohon perlindungan dan berkah dalam kehidupan umat manusia yang meyakininya, sedangkan manfaatnya sebagai tempat suci yang bersifat Keramat. (3). syarat dan proses mendirikan Keramat bagi umat Hindu Kaharingan adalah manenung/mangundik (memohon petunjuk) untuk mengetahui kapan dan dimana pendirian keramat, siapa rohaniawan yang memimpin upacara, sarana (sesajen) apa saja yang diperlukan untuk dipersembahkan. Mamapas dilokasi didirikan Keramat, Manawur bertujuan untuk memohon izin kepada penguasa alam semesta.
\end{abstract}

\section{Kata Kunci : Filosofi, Keramat,}

\section{Pendahuluan}

Akulturasi budaya agama Hindu Kaharingan menurut perkiraan telah ada sejak nenek moyang dulu kala yang pada asal mulanya disebut Agama Helu. Di Kalimantan Tengah khususnya, agama Hindu Kaharingan 
merupakan sebuah tradisi dan ritual adat istiadat yang turun temurun dari nenek moyang, sehingga melahirkan kearifan lokal yang mampu menciptakan suasana harmonis dalam kehidupan masyarakat Kalimantan Tengah. Upacara mendirikan Keramat adalah upacara pembangunan Keramat (berbentuk seperti rumah kecil) yang bertujuan untuk memberikan batasbatas antara manusia dengan mahluk gaib yakni dengan cara mendirikan sebuah keramat untuk tempat tinggal dari pada mahluk halus tersebut. Hal ini janganlah kita artikan secara sempit pembuatan Keramat ini hanyalah sebagai simbol penghormatan manusia kepada mahluk halus agar tidak saling mengganggu kehidupan masing-masing.

Walaupun di tengah gencarnya arus modernisasi dan globalisasi serta letak geografis serta pengaruh dari budaya luar yang berada di tengah Kota/Kabupaten, masyarakat Hindu kaharingan tetap setia menjalankan tradisi ritual tersebut. Hal inilah yang menimbulkan keinginan penulis meneliti lebih jauh mengenai upacara mendirikan Keramat. Di balik tradisi tersebut Hindu Kaharingan di Kalimantan Tengah yang merupakan pilar utama pencetak-pencetak umat Hindu yang berkualitas dan siap bersaing pada arus globalisasi dan pembangunan umat Hindu yang bermartabat, upacara mendirikan Keramat dirasakan sangat penting guna menjaga keharmonisan antara manusia dengan mahluk gaib yang ada di sekitar wilayah desa agar tidak terjadi sesuatu hal yang tidak diinginkan. Karena dengan menjaga hubungan yang tidak saling mengganggu kepentingan masing-masing maka akan tercipta suasana yang aman tanpa merasa keadaan yang tidak aman.

Pelaksanaan upacara mendirikan Keramat bagi masyarakat Hindu Kaharingan juga dapat menyesuaikan tradisi daerah masing-masing yang melaksanakan upacara tersebut tidak semua orang bisa melaksanakan, karena memiliki syarat tertentu dan memiliki pengetahuan serta keahlian khususnya pelaksanaan Balian/Manawur. Basir/Pisor adalah orang yang berpengalaman sebagai pelaksana upacara tersebut tentunya tidak bisa lepas dari ajaran yang telah mereka pelajari pada saat berguru, sehingga 
pelaksanaan upacara ritual tersebut kelihatannya berbeda-beda, namun tujuannya adalah sama, bahasa yang digunakan oleh para basir adalah menggunakan bahasa Sangiang (Bahasa Hatalla/Tuhan).

\section{Filosofi Keramat bagi umat Hindu Kaharingan}

Keramat dalam ajaran Agama Hindu Kaharingan tetap di pertahankan dari generasi ke generasi sampai sekarang bahkan dimasa-masa yang akan datang. Maka oleh sebab itulah keberadaan keramat tidak pernah hilang oleh kemajuan zaman, oleh sebab itulah kita sebagai generasi penerus umat Hindu Kaharingan sudah sepatutnya untuk melestarikan kebudayaan yang sudah di tinggalkan oleh nenek moyang yang telah mewariskan kepada kita.

Filosofi Keramat adalah suatu kepercayaan terhadap kehidupan dan alam yang dapat membantu menjaga keharmonisan, keserasian dan kedamaian bagi umat manusia yang mempercayainya, akan tetapi bagi yang tidak meyakini adanya Keramat tersebut, maka tidak akan ada perlidungan bagi kehidupannya karena umat Hindu Kaharingan dianggap memuja setan atau menyembah berhalla, namun kita sebagai umat yang bertaqwa kepada tuhan Yang Maha Esa jangan berkecil hati karena hal itu hanya merupakan simbol untuk mendekatkan diri kita terhadap Tuhan. Keramat adalah merupakan sebuah tempat pemujaan kepada leluhur (mamben patahu) yang menjaga lingkungan semesta alam, maka oleh sebab itu umat Hindu Kaharingan selalu menjaga dan memelihara Keramat sebagai tempat bertahta Mamben Patahu.

\section{Fungsi Keramat bagi umat Hindu Kaharingan}

\section{a. Fungsi Religius}

Fungsi Keramat bagi umat Hindu Kaharingan merupakan suatu sistem dari unsur kebudayaan dalam hal ini mengandung nilai fungsi upacara keagamaan yang terdiri dari fungsi yang pertama merupakan sara ekspresi simbolis untuk mewujudkan konsepi-konsepsi nilai-nilai keagamaan, khususnya yang berkenaan dengan kekuatan-kekuatan gaib 
tertentu, sedangkan fungsi yang kedua merupakan ekspresi simbolis untuk menyalurkan tanggapan-tanggapan kesan atas alam beserta sifat-sifatnya maupun atas konsep budaya tertentu melalui kekuatan visual yang terencana (Edi Sedyawati, 2010:12).

Segala Tindakan yang dilakukan manusia dalam realitas hidup penuh dengan simbol yang mempunyai fungsi bagi orang yang melakukan atau orang dalam suatu kelompok yang mungkin orang lain belum tahu.

Sesuai teori interaksionisme simbolik. Fungsi Keramat bagi umat Hindu Kaharingan mempunyai fungsi yang tinggi dalam kehidupan manusia, karena pelaksanaan terjadi adanya interaksi sosial masyarakat yang mempunyai hubungan dan melengkapi dalam setiap fungsinya. Menurut Danel L. Pals (2001:180) bahwa upacara-upacara yang dilakukan oleh masyarakat merupakan suatu tindakan kehidupan yang tidak bisa ditinggalkan. Hal itu sesuai dengan pandangan agama Hindu bahwa hidup adalah suatu yajna (korban) atau pemujaan yang harus dilakukannya sepanjang masa, karena alam semesta termasuk manusia di ciptakan tuhan dengan yajna. Sebagai balas budhi dan rasa bhakti manusia melaksanakan yajna (upacara) kepada tuhan beserta segala makhluk ciptaannya demi tercipta kehidupan yang harmonis.

Upacara mendirikan Keramat sebagai tindakan ritual yang mempunyai fungsi religius untuk memuja tuhan dan sesama manusia dalam hal ini suatu persembahan yang dilakukan rohaniwan (Pisor) telah banyak berkorban untuk membantu proses pelaksanaan upacara mendirikan Keramat dengan menggunakan berbagai sarana bersifat sakral atau profan kaya akan simbol. Sarana dan korban yang di persembahkan merupakan simbol rasa cinta dan bhakti untuk memuja Tuhan beserta manifestasinya. Sarana dan prasarana yang menjadi pusat fungsi Keramat mempunyai simbolsimbol religius dari sifat dan perwujudan Tuhan dalam memberikan kekuatan dalam persatuan kepada manusia Karena dengan pemujaan atau upacara manusia yajna sebagai wujud bhakti dan persembahan untuk mendekatkan hubungan kepada tuhan, sesama manusia maupun manusia 
dengan lingkungan. Hal tersebut sangat sesuai dengan ajaran agama Hindu konsep Tri Hita Karana yaitu terjalinnya hubungan yang harmonis antara manusia kepada Tuhan, manusia dengan sesamanya dan manusia dengan alam.

Keramat didirikan dengan suatu upacara ritual, semacam itu berarti si pemuja, membantu mengumpulkan dan menyebarluas- kan pengaruh atau kekuatan ketuhanan, pemuja berharap akan memperoleh rahmat Tuhan melalui para leluhur penjaga alam semesta (Wach,Joachim.1992:170). Upacara yang dilakukan dengan kepercayaan dan bhakti yang tinggi akan mempunyai pengaruh atau membangkitkan ketuhanan terhadap segala sesuatu yang dianggap sakral, demikian juga karena kasih Tuhan manusia akan menerima rahmatNya, sebagai ungkapan rasa syukur dan terima kasih karena telah diberikan keselamatan, keharmonisa dan kedamaian.

Menurut bagus (dalam I. Gede mudana, 2003 : 87) “aspek fungsi merupakan hasil kerja yang teratur, terurut dan terpandu yang mengacu pada bagaimana (epistemology)". Fungsi biasanya dianalisis dalam kaitannya dengan manfaat, mengapa suatu tindakan, interaksi dalam ilmu sosial dilaksanakan. Fungsi mengandaikan bahwa setiap unsur dalam struktur sosial memilki tujuan masing-masing.

Sistem sosial masyarakat yang terdiri dari beberapa bagian sub sistem mempunyai fungsi tertentu yang membentuk struktur sosial untuk kelangsungan dan keseimbangan masyarakat secara harmoni. fungsi Keramat yang terdapat di Kalimantan Tengah adalah suatu tindakan budaya manusia yang tercipta dari berbagai struktur masyarakat yang mempunyai fungsi dan tujuan yang luhur dalam menciptakan keseimbangan, keharmonisan dan keselamatan hidup.

Sesuai dengan teori konsep warnasrama dharma dalam mendirikan Keramat yang terdapat di Kalimantan Tengah mempunyai fungsi yang penting dalam kehidupan manusia. Menurut Daniel L. Pals (2001 : 180) bahwa kepercayaan yang dikemukakan dalam totemisme bukanlah hal yang terpenting tentang totemisme tetapi ritual-lah yang terpenting. Lebih lanjut ia 
menjelaskan, dalam pandangan Durkheim "cult" (dari kata latin cultus "pemuja") yang terdiri atas peristiwa-peristiwa tertentu adalah inti kehidupan bersama suatu Klan. Artinya upacara-upacara yang dilakukan oleh masyarakat merupakan suatu tindakan kehidupana yang tidak bisa ditinggalkan. Hal itu sesuai dengan pandangan agama Hindu bahwa hidup adalah suatu yajna (korban) atau pemujaan yang harus dilakukan sepanjang masa, karena alam semesta termasuk manusia diciptakan Tuhan dengan yajna. Sebagai balas budi dan rasa bhakti manusia melaksanakan yajna (upacara) kepada Ranying Hatalla Langit atau Tuhan Yang Maha Esa beserta segala mahluk ciptaan-Nya demi tercipta kehidupan yang harmonis.

Dalam melaksanakan upacara mendirikan Keramat bagi umat Hindu Kaharingan mengandung makna dan fungsi yang sangat mendasar dan harus dilaksanakan. Sebagaimana telah difirmankan Ranying Hatalla Langit kepada Raja Uju Hakanduang disaat mereka melaksanakan upacara-upacara sebagai contoh atau pedoman kepada keturunan raja Bunu melaksanakan upacara mendirikan Keramat bagi umat Hindu Kaharingan, walaupun tata caranya berbeda masing-masing DAS yang ada di Kalimantan Tengah itu menjadi keunikan bagi masyarakat.

Fungsi mendirikan Keramat bagi umat Hindu Kaharingan dilakukan untuk mentralisirkan, membersih dan mesucikan kehidupan manusia yang mengalami hal-hal yang tidak baik terjadi di kampung halaman tersebut, agar mereka mendapakan keselamatan, keharmonisan dan kesejahteraan dalam menjalankan kehidupan yang akan datang.

Fungsi upacara mendirikan Keramat bagi umat Hindu Kaharingan yaitu memberikan suatu persembahan kepada para bhuta kala yang menjaga keseimbangan alam semesta, agar diberikan keselamatan, keharmonisan dan kesejahteraan, atas berkat dari Ranying Hatalla Langit atau Tuhan yang Maha Esa melalui para leluhur (malaikat-malaikanya). Untuk setiap doa, cita-cita dan ucapan-ucapan yang keluar dari hati maupun mulut, terutama orang yang mengalami musibah misalnya rumahnya terbakar, maka ia lakukan upacara mendirikan Keramat. Untuk itu terutama keluarga dengan 
senang hati dan rela berkorban melakukan upacara, karena doa dan permohonan mereka dikabulkannya.

\section{b. Fungsi sosial}

Manusia mencita-citakan keselarasan hidup didunia dan diakhirat. Untuk mencapai hal tersebut maka fungsi agama memegang peranan yang sangat penting dalam kehidupan bermasyarakat. Fungsi-fungsi agama tersebut juga sesuai dengan fungsi sosial dalam filosoi mendirikan Keramat bagi umat Hindu Kaharingan sebagai aplikasi ajaran agama Hindu Kaharingan.

Menurut Soelaeman Munandar (2007:160), menyebutkan fungsifungsi agama dalam pengukuhan nilai-nilai yang bersumber pada kerangka acuan yang bersifat sakral, maka normanya pun dikukuhkan dengan sanksisanksi sakral. Dalam setiap masyarakat sanksi sakral mempunyai kekuatan memaksa istimewa, karena ganjaran hukumannya bersifat duniawi.

Fungsi agama dibidang sosial adalah fungsi penentu, dimana agama menciptakan suatu ikatan bersama, baik diantara anggota-anggota masyarakat maupun kewajiban-kewajiban sosial yang membantu mempersatukan mereka. Fungsi agama sebagai sosialisasi individu, ialah individu pada saat ia tumbuh menjadi dewasa, memerlukan sistem nilai sebagai semacam tuntunan umum untuk mengarahkan aktivitasnya dalam masyarakat dan berfungsi sebagai tujuan akhir pembangunan kepribadiannya sebagai peningkatan "moralisasi" individu maupun moralisasi masyarakat Indonesia pada umumnya.

\section{Syarat dan poses mendirikan Keramat bagi umat Hindu Kaharingan}

Berdasarkan hasil wawancara dengan beberapa nara sumber menyatakan bahwa :

"syarat yang digunakan dalam mendirikan keramat tergantung dari hasil manenung atau mengundik (memohon petunjuk), tetapi pada umumnya syarat yang digunakan yaitu: Tampung tawar, Parapen, Garu Manyan, Undus, Behas tawur, Sawang, Dawen Sambelum, Piring 3 dan gelas 2, Amak Dare, Telor ayam 7 biji, Ayam 2 ekor, 1 untuk mamapas 
bahan Keramat dan 1 untuk sesajen, wadai cucur 7, Lamang 7 , Ketupat 7, Panduduk yang dilengkapi dengan giling pinang 7, Roko 7, Behas Hambaruan bermakna sebagai berkat dan anugrah yang diberikan Tuhan. Babi 1 ekor, Manas untuk keperluan diikatkan kepada orang yang punya upacara, orang-orang yang nmengerjakan keramat dan rohaniawan yang memimpin upacara Yajna (upah/laluh) rohaniawan pelaksana upacara".

Penjelasan dari beberapa Syarat tersebut di atas yaitu sebagai berikut:

a. Tampung Tawar berfungsi untuk menampung tawar sebagai menetralisir dari hal yang tidak baik.

b. Parapen berfungsi untuk tempat membakar garu manyan.

c. Garu manyan berfungsi untuk pengharum atau untuk pemanggil rohroh yang ada pada beras tawur agar bisa datang jika dibutuhkan pada saat menawur.

d. Undus berfungsi untuk mentralisirkan dari segala hal yang tidak baik.

e. Behas Tawur berfungsi sebagai media komunikasi dengan mahluk halus atau roh yang tidak kelihatan secara kasat mata.

f. Sawang berfungsi berfungsi sebagai simbol keberuntungan dalam kehidupan manusia.

g. Dawen sambelum berfungsi sebagai simbol hidup sejahtera, damai dan harmonis.

h. Piring berfungsi untuk tempat darah babi, ayam dan tempat sesajen.

i. Gelas berfungsi untuk tempat air minum dan tuak

j. Amak Dare berfungsi untuk alas tempat peralatan upacara.

k. Telor ayam berfungsi untuk sesajen yang dimasukkan dalam keramat jika sudah selesai.

1. AyamHidup dan Ayam Mati berfungsi untuk mamapas dan sesajen

m. Cucur,lamang, ketupat berfungsi untuk sesajen

n. Babi berfungsi untuk sesajen 
Adapun Proses pendirian Keramat adalah melalui beberapa rangkaian yang harus dilaksanakan upacaranya yaitu:

Menenung dan mengundik (memohon petunjuk) yang bertujuan untuk mengetahui;

a. Kapan dan dimana keramat didirikan.

b. Siapa rohaniawan yang memimpin upacara pendirian pasah keramat

c. Sarana (sesajen) apa saja yang diperlukan untuk di persembahkan.

d. Mamapas dilaksanakan di lokasi / tempat yang akan didirikan pasah keramat, termasuk bahan - bahan yang akan dijadikan alat keramat itu bertujuan untuk penyucian.

e. Manawur, yang tujuan untuk memohon izin dan berkat selama kegiatan dilangsungkan serta sebagai mediasi untuk mengundang para manisfestasi Tuhan (Ganan sahur parapah) untuk menerima sesajen/yajna yang dipersembahkan.

Sebelum Keramat didirikan terlebih dahulu melaksanakan manenung atau mengundik supaya kita tahu apa saja sarana yang di gunakan dan dimana tempat pendirian Keramat, karena mendirikan Keramat tidak boleh sembarangan tempat. Jika kita mendirikan Keramat sembarangan tempat maka kita bisa sakit-sakitan.

Berdasarkan pandangan Hukum Hindu apabila syarat-syarat dalam mendirikan Keramat tersebut tidak lengkap sesuai petunjuk hasil manenung/mangundik, maka akan membawa suatu akibat yang tidak baik untuk keluarga atau masyarakat yang melaksanakan upacara mendirikan Keramat tersebut. Dalam pelaksanaan mendirikan Keramat bagi umat Hindu Kaharingan selalu berhati-hati mempersiapkan syarat-syarat upacara mendirikan Keramat.

\section{Kesimpulan}

Berdasarkan uraian diatas maka dapat diambil kesimpulan sebagai berikut :

1. Filosofi Keramat bagi umat Hindu Kaharingan dari dulu hingga sekarang masih di taati dan diyakini, hal itu mendapat pengakuan dari 
masyarakat secara turun temurun dan di dukung oleh kepercayaan agama Hindu Kaharingan terkait dengan kepercayaan yang gaib dan sakral.

2. Fungsi dan manfaat Keramat adalah berfungsi sebagai tempat pemujaan bagi umat Hindu Kaharingan untuk memohon perlindungan dan berkah dalam kehidupan umat manusia yang meyakininya, sedangkan manfaatnya sebagai tempat suci yang bersifat Keramat.

3. Syarat dan Proses mendirikan Keramat bagi umat Hindu Kaharingan di adalah manenung/mangundik (memohon petunjuk) untuk mengetahui kapan dan dimana pendirian keramat, siapa rohaniawan yang memimpin upacara, sarana (sesajen) apa saja yang diperlukan untuk dipersembahkan. Mamapas dilokasi didirikan Keramat, Manawur bertujuan untuk memohon izin kepada penguasa alam semesta.

\section{DAFTAR PUSTAKA}

Pals, Daniel L. 2001. Dekonstruksi Kebenaran, Kritik Tujuh Teori Agama. Jakarta : CV. Rajawali

Mudana,I.Gede dkk.2013. Kearifan Lokal Suku Helong.Yogyakarta: Penerbit Ombak

Sedayawati Edi.2010. Budaya Indonesia Kajian Arkeologi, Seni dan sejarah. Jakarta: PT.Raja Grafindo Persada.

Soelaeman, Munandar.2007. Ilmu Budaya Dasar. Bandung: Refika Aditama.

Wach. Joachim. 1992. Ilmu Perbandingan Agama. Jakarta: CV. Rajawali 